\title{
DIFFERENCES IN THE POTENTIAL MUTAGENICITY OF RESIN-, SILICONE-, AND BIOCERAMIC-BASED SEALERS ON LYMPHOCYTES: A PROTEIN EXPRESSION ANALYSIS
}

\author{
SANI SURYADARMA, KAMIZAR*, ENDANG SUPRASTIWI, RATNA MEIDYAWATI, MAIDA FITRI \\ Department of Conservative Dentistry Department, Faculty of Dentistry, Universitas Indonesia, Jakarta, Indonesia. \\ E-mail: kamizar_kz@yahoo.com
}

Received: 27 August 2018, Revised and Accepted: 07 February 2019

\begin{abstract}
Objective: The objective of this study was to compare the potential mutagenicity of resin-, silicone-, and bioceramic-based sealers on protein expression in human lymphocytes. There has been limited research on resin-, silicone-, and bioceramic-based sealers effects on protein expression in lymphocytes.
\end{abstract}

Methods: Nine samples of each sealer were incubated in $2 \mathrm{~mL}$ human blood for 1, 3, and 7 days. Then, the isolated lymphocytes are observed for protein separation by electrophoresis method. Profile of protein bands observed and data were analyzed statistically by Kruskal-Wallis and post hoc Mann-Whitney.

Results: Although no statistically significant differences in protein bands were observed among the resin-, silicone-, and bioceramic-based sealers $(\mathrm{p}=0.111)$, there was a statistically significant difference between the resin- and silicone-based sealers on the $1^{\text {st }}$ day $(p=0.046)$ and $3^{\text {rd }}$ day $(p=0.046)$ and between the silicone- and bioceramic-based sealers on the $1^{\text {st }}$ day $(p=0.046)$. Thus, the present study shows that there were differences in the potential mutagenicity on the $1^{\text {st }}$ day; resin was potentially more mutagenic followed by bioceramic and silicone. On the $3^{\text {rd }}$ and $7^{\text {th }}$ days, bioceramic was potentially more mutagenic followed by resin and silicone.

Conclusion: The manuscript describes the study in detail and concludes that resin was potentially more mutagenic followed by bioceramic- and silicone-based sealers.

Keywords: Root canal sealers, Bioceramic, Protein expression, Lymphocyte, Mutagenicity, Resin, Silicone.

(C) 2019 The Authors. Published by Innovare Academic Sciences Pvt Ltd. This is an open access article under the CC BY license (http://creativecommons. org/licenses/by/4. 0/) DOI: http://dx.doi.org/10.22159/ijap.2019.v11s1.16021

\section{INTRODUCTION}

The main purpose of root canal treatment is to eliminate the microorganisms and prevent the reoccurrence of infection in the future. To achieve successful treatment, there is a need for closure of the root canal to prevent bacterial proliferation, which can cause infection in the root canal and periapical tissue. The obturation material and root canal sealer work synergistically, resulting in hermetic obturation of the root canal [1].

Root canal sealers serve to fill the space between the gutta-percha and the root canal walls, and accessory canals, and as a lubricant during the obturation procedure to ensure hermetic and tight obturation [2]. Obturation of the root canal is carried out until apical constriction occurs; however, currently, there exists the phenomenon of obturation with the extrusion of sealers (sealer puff) beyond apical constriction and subsequent contact with periapical tissue $[3,4]$.

Hence, root canal sealers must be non-toxic and contribute to the healing process of the periapical lesion [5]. Sealers should have a bacteriostatic effect and be biocompatible, causing no irritation to the periapical tissues [6]. Biocompatibility is defined as the ability of a material to cause no biological response when applied to tissues or cells in the human body. The biocompatibility of a material depends on its expected physical function and biological response. Poor biocompatibility results in cytotoxicity, genotoxicity, mutagenicity, and the potential to cause malignancy [7].

Mutagenicity is the ability of an agent to cause a mutation in cellular DNA; such a mutation can occur due to a fault during replication, repair, or recombination of DNA that causes substitution, insertion, or deletion of DNA base pairs. Cellular DNA can undergo mutation when the cell is exposed to chemicals, physical agents, or radiation. Permanent damage to DNA can also occur in defense cells found in the periapical area, including lymphocytes [8].

A change in the chemical composition of DNA can change the processes of transcription and translation, ultimately altering protein synthesis, which can change cellular and organismal metabolic processes. These changes can cause the differential expression of many proteins, which may be due to inflammatory processes or changes in genes (mutations) that occur as a result of the exposure of lymphocytes to mutagenic agents (physical or chemical) [9,10].

Root canal sealers are chemical agents that are potentially mutagenic. Miletic et al. studied AH26 and AH Plus resins for their effect on human lymphocytes following incubation for $1 \mathrm{~h}, 24 \mathrm{~h}$, and 7 days. This experimental work found no chromosomal alterations or mutations in the lymphocytes [11]; however, according to Sousa et al. that evaluate the intraosseous biocompatibility of AH Plus, AH Plus sealer can cause an inflammatory response in the guinea pigs jaw, into experimental periods of 4 and 12 weeks [12]. The silicone sealer, GuttaFlow, has been shown to have a better biocompatibility than the AH Plus sealer [13] and caused no chromosomal alterations in human lymphocytes in vitro [14]. Bioceramic sealers induce biomineralization and have a good biocompatibility; however, research regarding these sealers is still very limited [15].

Since there is a difference in the results presented in literature and limited research regarding the effects of resin-, silicone-, and bioceramicbased sealers on protein expression in lymphocytes, the present study 
sought to compare these three types of sealers. Incubation periods of 1 and 3 days were used, since the life cycle of lymphocytic cell ranges from 1 to 3 days and 7 days, since there is evidence that bioceramic sealers can take this long to set [16].

Sealers, as chemical agents, can potentially irritate when extruded to the periapical tissue, affecting the life cycle of surrounding cells, particularly lymphocytes. At present, resin-based sealers are most commonly used, while more novel materials such as bioceramic- and silicone-based sealers have emerged. The purpose of the present study was to evaluate the differences in potential mutagenicity of resin-, silicone-, and bioceramic-based sealers with respect to changes in protein expression in lymphocytes following a 1-, 3-, and 7-day incubation.

\section{METHODS}

This study was approved by the local ethics committee, patient approval and consent were made before obtaining blood sample from one human sample age 28, female, not smoking, with no systemic disease. Sealers used for this study were resin based, AH Plus (Dentsply/ Maillefer, Konstanz, Germany), bioceramic based, IRoot SP (Innovative Bioceramix Inc., Vancouver, Canada), and silicone based, GuttaFlow bioseal (Coltene-Whaledent, Langenau, Germany). $2 \mathrm{ml}$ of blood was added to wells containing $1.5 \mathrm{~mL}$ culture medium (RPMI, FBS, PenStrep), mixed with sealers, and incubated for 1,3 , and 7 days at room temperature. The wells were subsequently flushed with phosphatebuffered saline (PBS) for the isolation of lymphocytes.

Samples of blood and $3.5 \mathrm{~mL}$ medium mixed with $3 \mathrm{~mL}$ PBS were added to $3 \mathrm{~mL}$ Histopaque and centrifugated for $30 \mathrm{~min}$ at $1500 \mathrm{rpm}$, resulting in three layers of liquid. Lymphocytes were separated from the layer between the Histopaque and blood plasma layers, transferred to a $15-\mathrm{mL}$ tube containing $5 \mathrm{~mL}$ PBS (pH 7.4), and centrifugated for $15 \mathrm{~min}$ at $1000 \mathrm{rpm}$. The supernatant was flushed out, and $10 \mu \mathrm{l}$ of each resuspended pellet was added to the same volume of sample buffer containing $\beta$-mercaptoethanol.

Table 1: The median and $p$ values of the effects of resin-, silicone-, and bioceramic-based sealers on the number of lymphocyte protein bands following a 1-, 3-, and 7-day incubation

\begin{tabular}{llllll}
\hline Group & $\mathbf{n}$ & \multicolumn{2}{l}{ Incubation time median (Min-Max) } & \multirow{2}{*}{ p-value } \\
\cline { 2 - 5 } & & $\mathbf{1}$ day & $\mathbf{3}$ days & $\mathbf{7}$ days & \\
\hline Resin & 9 & $4.00(3-5)$ & $5.00(3-6)$ & $3.00(3-5)$ & 0.111 \\
Silicone & 9 & $10.00(9-10)$ & $7.00(2-8)$ & $3.00(3-5)$ & \\
Bioceramic & 9 & $6.00(4-8)$ & $4.00(1-6)$ & $2.00(2-4)$ & \\
\hline
\end{tabular}

*Kruskal-Wallis test, with $\mathrm{p}<0.05$
About $20 \mu \mathrm{l}$ of lymphocytes from each well were transferred to a sodium dodecyl sulfate-polyacrylamide gel electrophoresis (SDS-PAGE) gel and separated by electrophoresis for $120 \mathrm{~min}$ at $120 \mathrm{~V}$ and $40 \mathrm{~mA}$. The gel was subsequently stained with Coomassie Brilliant Blue R-250 dye for $1 \mathrm{~h}$, destained for $2 \mathrm{~h}$, and scanned using a Bio-Rad ${ }^{\circledR}$ Molecular Imager $^{\mathrm{TM}} \mathrm{Gel} \mathrm{Doc}^{\mathrm{TM}} \mathrm{XR}+$ connected to a personal computer to observe the protein profiles.

The protein profile of lymphocytes was analyzed by one-dimension SDS-PAGE, and calculation was performed by counting the number of protein bands. The data were subsequently tested by a Kruskal-Wallis non-parametric test using the SPSS v22 software. Normally distributed data were tested using a one-way analysis of variance parametric test, and abnormally distributed data were tested using the Kruskal-Wallis non-parametric test, to compare all materials and incubation times $(1,3$, and 7 days), with a statistical significance value of $p<0.05$.

\section{RESULTS}

The results of the statistical tests for resin-, silicone-, and bioceramicbased sealers are presented in Table 1.

There was no statistically significant difference in the number of protein bands $(p \geq 0.05)$ between the resin-, silicone-, and bioceramic-based sealers, indicating no significant difference in potential mutagenicity between the three materials.

To evaluate differences among groups, the data were subsequently which is shown in Table 2 analyzed using the Mann-Whitney post hoc test.

There was no significant difference in the effect of the resin- or bioceramic-based sealers on lymphocyte protein expression on days 1,3 , or 7 ; however, there was a significant difference in the effect of the silicone-based sealer on lymphocyte protein expression on days 1,3 , and 7 . There were significant differences in the effects of resin-, silicone-, and bioceramic-based sealers on lymphocyte protein expression on day 1 . There were no significant differences in the effects of the resin-, silicone-, or bioceramic-based sealers on lymphocyte protein expression on days 3 and 7 .

The mean number of protein bands present following each incubation time is shown in Fig. 1 . On the $1^{\text {st }}$ day, the largest number of protein bands was found following incubation with silicone followed by bioceramic and resin. The lower the number of protein bands, the less proteins were expressed.

On the $3^{\text {rd }}$ day, the largest number of protein bands was found following incubation with silicone followed by resin and bioceramic, while on the $7^{\text {th }}$ day, the protein expression seen in the presence of all sealers tended to be decreased as compared with the $1^{\text {st }}$ and $3^{\text {rd }}$ days.

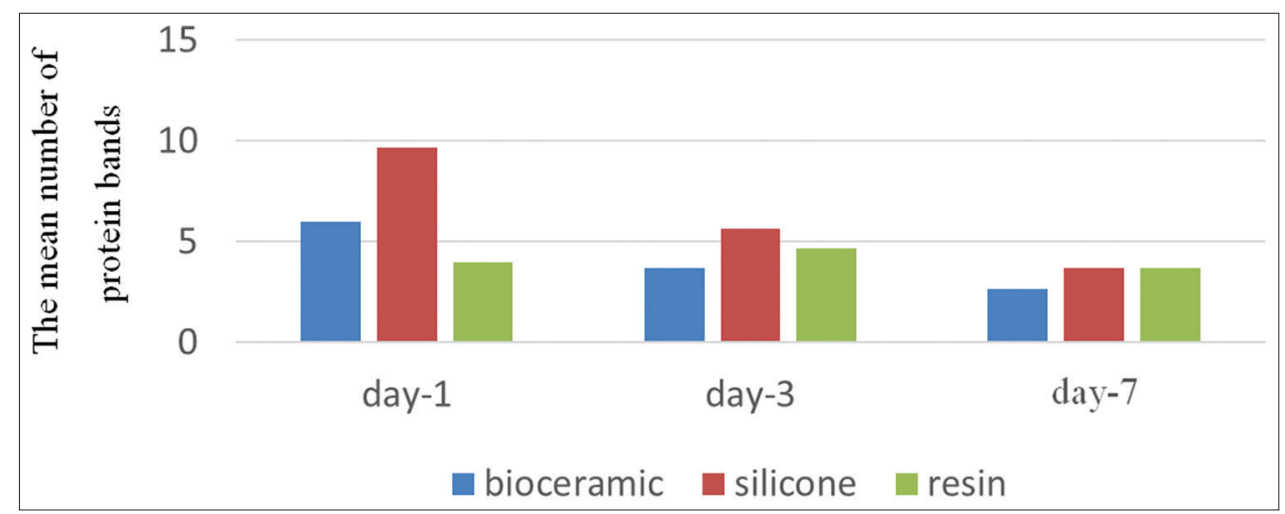

Fig. 1: Comparison of the mean number of protein bands following incubation with bioceramic-, silicone-, and resin-based sealers for different periods of time 
Table 2: Significance of the effect of each sealer on the number of protein bands following a 1-, 3-, and 7-day incubation

\begin{tabular}{|c|c|c|c|c|c|c|c|c|c|c|}
\hline \multirow[t]{2}{*}{ Material } & \multirow[t]{2}{*}{ Incubation } & \multicolumn{3}{|l|}{ Resin } & \multicolumn{3}{|c|}{ Silicone } & \multicolumn{3}{|c|}{ Bioceramic } \\
\hline & & 1 day & 3 days & 7 days & 1 day & 3 days & 7 days & 1 day & 3 days & 7 days \\
\hline \multirow[t]{3}{*}{ Resin } & 1 day & - & 0.500 & 0.637 & & & & & & \\
\hline & 3 days & & - & 0.346 & & & & & & \\
\hline & 7 days & & & - & & & & & & \\
\hline \multirow[t]{3}{*}{ Silicone } & 1 day & $0.046^{*}$ & & & - & $0.046^{*}$ & $0.043^{*}$ & & & \\
\hline & 3 days & & 0.513 & & & - & 0.507 & & & \\
\hline & 7 days & & & 1.000 & & & 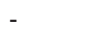 & & & \\
\hline \multirow[t]{3}{*}{ Bioceramic } & 1 day & 0.184 & & & $0.046^{*}$ & & & - & 0.261 & 0.072 \\
\hline & 3 days & & 0.658 & & & 0.275 & & & - & 0.653 \\
\hline & 7 days & & & 0.261 & & & 0.261 & & & - \\
\hline
\end{tabular}

*Mann-Whitney post hoc test, with $\mathrm{p}<0.05$ considered statistically significant

\section{DISCUSSION}

A change or mutation in a gene can cause alterations in protein expression. Gene mutation occurs during the translation or transcription processes of protein synthesis. A change in the nucleotide sequence can lead to cessation of protein synthesis, due to a change in lymphocyte gene expression caused by the exposure of physical or chemical mutagenic agents $[9,10]$.

Nine samples of each sealer were incubated with lymphocytes for 1,3 , and 7 days. The results (Table 1 ) show that on the $1^{\text {st }}$ day of exposure to the sealers, the highest number of protein bands was seen in the silicone-based sealer (GuttaFlow) group, while in the bioceramic-based sealer (IRoot) group, there were 4-6 protein bands, and in the resinbased sealer (AH Plus) group, there were 3-5 protein bands.

From the mean number of protein bands seen in Fig. 1, the silicone-based sealer showed the induction of higher protein expression, especially on the $1^{\text {st }}$ and $3^{\text {rd }}$ days, as compared with the bioceramic- and resin-based sealers. This is in accordance with Accardo et al. who showed greater cell viability of periodontal ligaments with silicone (GuttaFlow) as compared with resin (AH Plus Jet), indicating better biocompatibility [17].

The mutagenic potential of resin sealers, possibly caused by the epoxy resin, bisphenol A (BPA) was explained in a study by Schweikl et al. [18]. Moreover, according to Ersev et al. and Schweikl et al., resin sealers have a mutagenic effect in vitro and in vivo, especially immediately after mixing [19]; however, the mutagenic potential was not seen $24 \mathrm{~h}$ after setting [20]. In addition to containing BPA, resin sealers have also been shown to release a small amount of formaldehyde after setting, based on a report by Leonardo et al. [21].

However, according to Van Landuyt et al., resin sealer extruded to periapical tissue caused no DNA destruction [22], which is in accordance with Geurtsen and Leyhausen who showed that AH Plus has no genotoxic or mutagenic effects [23].

On the $3^{\text {rd }}$ day of exposure with the sealers, the highest number, 2-8, of protein bands was seen with the silicone-based sealer (GuttaFlow), while the number of protein bands seen with the resin-based sealer $\mathrm{AH}$ Plus) was 3-6 and with the bioceramic-based sealer (IRoot) was 1-6.

In the present study, the silicone-based sealer (GuttaFlow) had a better biocompatibility than the resin- and bioceramic-based sealers. This observation is supported by Saygili et al. who found that GuttaFlow was more biocompatible as compared with $\mathrm{AH}$ Plus following incubation with mouse fibroblasts for $3 \mathrm{~h}$, and 1,3 , and 7 days. This may be due to the bioactive glass content, consisting of silica, calcium oxide, sodium oxide, and phosphorus oxide. This material has osteoinductive properties and bonds mechanically with bone tissue [23].

A study by Bueno et al. in mouse subcutaneous tissue showed that bioceramic-based resins induce biomineralization and have good biocompatibility [14] while, according to Orrenius et al. and Midy et $a l$. , the concentration of calcium ions in bioceramic-based resins can induce cell damage $[16,24]$.

On the $7^{\text {th }}$ day of exposure, the highest number of protein bands, $3-5$, was seen with the resin-based (AH Plus) sealer, while the number of protein bands seen with the silicone-based (GuttaFlow) sealer was 3-5 and with the bioceramic-based (IRoot) sealer was 2-4. This is in accordance with Miletic et al., who studied the effect of resin-based sealers (AH26 and AH Plus) on human lymphocytes for $1 \mathrm{~h}, 24 \mathrm{~h}$, and 7 days, and found no chromosomal alterations or mutations [11].

The sample used in the present study was lymphocytes from human peripheral blood, which was also used by Brzovic et al. and Miletic et al. to observe mutagenicity through chromosomal aberration $[11,14]$. Lymphocytes have the highest sensitivity to DNA damage as compared with other cell types [25].

A change in DNA chemical composition can lead to alterations in the transcription and translation processes, which eventually affects protein synthesis and changes cellular and organismal metabolic processes [10]. Protein expression can be observed by SDS-PAGE.

The present study has some limitations. Samples were equalized by blood volume, which does not necessarily result in the same number of lymphocytes per well. This may have caused an imbalance in lymphocyte protein expression, accounting for the different numbers of protein bands in each condition. In the future, lymphocytes should be counted using a hemocytometer or automatic cell counter to increase accuracy.

In addition, blood samples were taken from only one relatively young individual (and therefore also one gender) with good systemic health; thus, the protein profile represented the expression of one individual's genes. In the future, samples from individuals varying in age, gender, and systemic health should be used for comparison.

Moreover, the difference in protein profiles could have also been caused by an unstable electric current, affecting the speed of protein migration. Furthermore, the longer that lymphocytes are kept, the more denaturation occurs, leading to cell lysis and protein damage. The current results support the need to continue to develop better endodontic sealers that combine the excellent sealing with acceptable biological properties for clinical applications.

\section{CONCLUSION}

There were differences in the potential mutagenicity on the $1^{\text {st }}$ day; the resin-based sealer was potentially more mutagenic followed by the bioceramic- and silicone-based sealers. On the $3^{\text {rd }}$ and $7^{\text {th }}$ days, bioceramic was potentially more mutagenic followed by resin and silicone. 


\section{CONFLICTS OF INTERESTS}

There are no conflicts of interest to declare.

\section{REFERENCES}

1. Tyagi S, Mishra P, Tyagi P. Evolution of root canal sealers: An insight story. Eur J Gen Dent 2013;2:199-213.

2. Ingle J, Bakland LK, Baumgartner JC. Endodontics. $6^{\text {th }}$ ed. Hamilton, Ontario: BC Decker Inc; 2008.

3. Ghanaati S, Willershausen I, Barbeck M, Unger RE, Joergens M, Sader RA, et al. Tissue reaction to sealing materials: Different view at biocompatibility. Eur J Med Res 2010;15:483-92.

4. Gutmann JL. Apical termination of root canal procedures---ambiguity or disambiguation? Evid Based Endod 2016;1:4.

5. Singh H, Markan S, Kaur M, Gupta G. Endodontic sealers: Current concepts and comparative analysis. Dent Open J 2015;2:32-7.

6. Poggio C, Arciola CR, Dagna A, Colombo M, Bianchi S, Visai L, et al. Solubility of root canal sealers: A comparative study. Int J Artif Organs 2010;33:676-81.

7. Sakaguchi RL, Powers JM. Biocompatibility and tissue reaction to biomaterials. In: Craig's Restorative Dental Materials. $13^{\text {th }}$ ed. Philadelphia, PA: Elsevier; 2012. p. 110-3.

8. Alberts B, Bray D, Hopkin K, Johnson A, Lewis J, Raff M, et al. Essential Cell Biology. $4^{\text {th }}$ ed. New York: Garlans Science; 2014.

9. Alberts B, Jonson A, Lewis J, Raff M, Roberts K, Walter P. Molecular Biology of the Cell. $6^{\text {th }}$ ed. New York: Garland Science; 2015.

10. Suharsono, Tjahtoleksono A, Jusuf M, Hartana A. Struktur Dan Ekspresi Gen. Bogor. Available from: http://www.web.ipb.ac.id/ tpb/ files/materi/genetika/strukturekspresi/strukturtextpdf.pdf.

11. Miletić I, Jukić S, Anić I, Zeljezić D, Garaj-Vrhovac V, Osmak M, et al. Examination of cytotoxicity and mutagenicity of AH26 and $\mathrm{AH}$ plus sealers. Int Endod J 2003;36:330-5.

12. Sousa CJ, Montes CR, Pascon EA, Loyola AM, Versiani MA. Comparison of the intraosseous biocompatibility of AH plus, endoREZ, and epiphany root canal sealers. J Endod 2006;32:656-62.
13. Bouillaguet S, Wataha JC, Tay FR, Brackett MG, Lockwood PE. Initial in vitro biological response to contemporary endodontic sealers. J Endod 2006;32:989-92.

14. Brzovic V, Miletic I, Zeljezic D, Mladinic M, Kasuba V, Ramic S, et al. In vitro genotoxicity of root canal sealers. Int Endod J 2009;42:253-63.

15. Bueno CR, Valentim D, Marques VA, Gomes-Filho JE, Cintra LT, Jacinto RC, et al. Biocompatibility and biomineralization assessment of bioceramic, epoxy, and calcium hydroxide-based sealers. Braz Oral Res 2016;30:1-9.

16. Midy V, Dard M, Hollande E. Evaluation of the effect of three calcium phosphate powders on osteoblast cells. J Mater Sci Mater Med 2001;12:259-65

17. Accardo C, Himel VT, Lallier TE. A novel guttaFlow sealer supports cell survival and attachment. J Endod 2014;40:231-4.

18. Schweikl H, Schmalz G, Stimmelmayr H, Bey B. Mutagenicity of AH26 in an in vitro mammalian cell mutation assay. J Endod 1995;21:407-10.

19. Ersev H, Schmalz G, Bayirli G, Schweikl H. Cytotoxic and mutagenic potencies of various root canal filling materials in eukaryotic and prokaryotic cells in vitro. J Endod 1999;25:359-63

20. Schweikl H, Schmalz G. The induction of micronuclei in V79 cells by the root canal filling material AH plus. Biomaterials 2000;21:939-44.

21. Leonardo MR, Bezerra da Silva LA, Filho MT, Santana da Silva R. Release of formaldehyde by 4 endodontic sealers. Oral Surg Oral Med Oral Pathol Oral Radiol Endod 1999;88:221-5.

22. Van Landuyt KL, Geebelen B, Shehata M, Furche SL, Durner J, Van Meerbeek B, et al. No evidence for DNA double-strand breaks caused by endodontic sealers. J Endod 2012;38:636-41.

23. Geurtsen W, Leyhausen G. Biological aspects of root canal filling materials-histocompatibility,cytotoxicity, and mutagenicity. Clin Oral Investig 1997; 1:5-11

24. Orrenius S, Zhivotovsky B, Nicotera P. Regulation of cell death: The calcium-apoptosis link. Nat Rev Mol Cell Biol 2003;4:552-65.

25. Pool-Zobel BL, Dornacher I, Lambertz R, Knoll M, Seitz HK. Genetic damage and repair in human rectal cells for biomonitoring: Sex differences, effects of alcohol exposure, and susceptibilities in comparison to peripheral blood lymphocytes. Mutat Res 2004;551:127-34 